\title{
COMBRETACEAE
}

\section{A NEW SPECIES OF COMBRETUM FROM NATAL}

Combretum mkuzense Carr \& Retief, sp. nov., a C. kirkii Laws. frutice semi-scandenti ramulis terminalibus rigidis nec sinuosis, inflorescentiis puberulis differt.

TYPE.-Natal, 2732 (Ubombo): Mkuze Game Reserve headquarters (-CA), Carr 187 (PRE, holo.; $\mathrm{K})$.

Large shrub up to $5 \mathrm{~m}$ tall, widely spreading (to $12 \mathrm{~m}$ ) with many near-horizontal lateral branches with apices sometimes twining; bark mainly smooth, pale buffcoloured with longitudinal reticulation and occasionally with dark grey bands, flaking; young branchlets light green, glabrous to sparsely puberulous and lepidote. Leaves opposite, exstipulate, petiolate; lamina elliptic to oblong-elliptic, $(30-) 45(-80) \times(15-) 20(-30)$ $\mathrm{mm}$, base rounded, apex obtuse or occasionally retuse, slightly discolorous, upper surface deep green, glabrous except for scales, sometimes with a few cilia at the base, veins slightly immersed, lower surface paler green, gla- brous except for scales and a few trichomes on the midrib, hairy pockets sometimes present, 5-7 pairs of lateral veins raised; petioles 4-9 mm long, lepidote, puberulous. Scales $45-85 \mu \mathrm{m}$ in diam., 8-celled with a number of tangential walls. Inflorescence a spike, up to $25 \mathrm{~mm}$ long, singly or in pairs at the apices of previous year's growth and in axils on current extensions; peduncle and rhachis light green, sparsely puberulous, densely lepidote. Flowers sessile, 4-merous; bracteoles $\pm 0,5 \mathrm{~mm}$ long, lepidote; lower receptacle $2-2,3 \mathrm{~mm}$ long including restriction at junction with upper receptacle, brownish green, sparsely puberulous with dense yellowish stalked scales; upper receptacle cupuliform, surrounding the disc, distal portion infundibuliform, overall length $\pm 3 \mathrm{~mm}$, width at sepal apices $\pm 3 \mathrm{~mm}$, green, sparsely puberulous with whitish scales. Sepals triangular, $\pm 0,8 \mathrm{~mm}$ long, apices fringed with short whitish hairs. Petals 4, pale green, spathulate, glabrous, $\pm 1,5 \mathrm{~mm}$ long. Stamens 8 ; filaments light green, 6-6,5 mm long; anthers light yellow, $1 \mathrm{~mm}$ long.

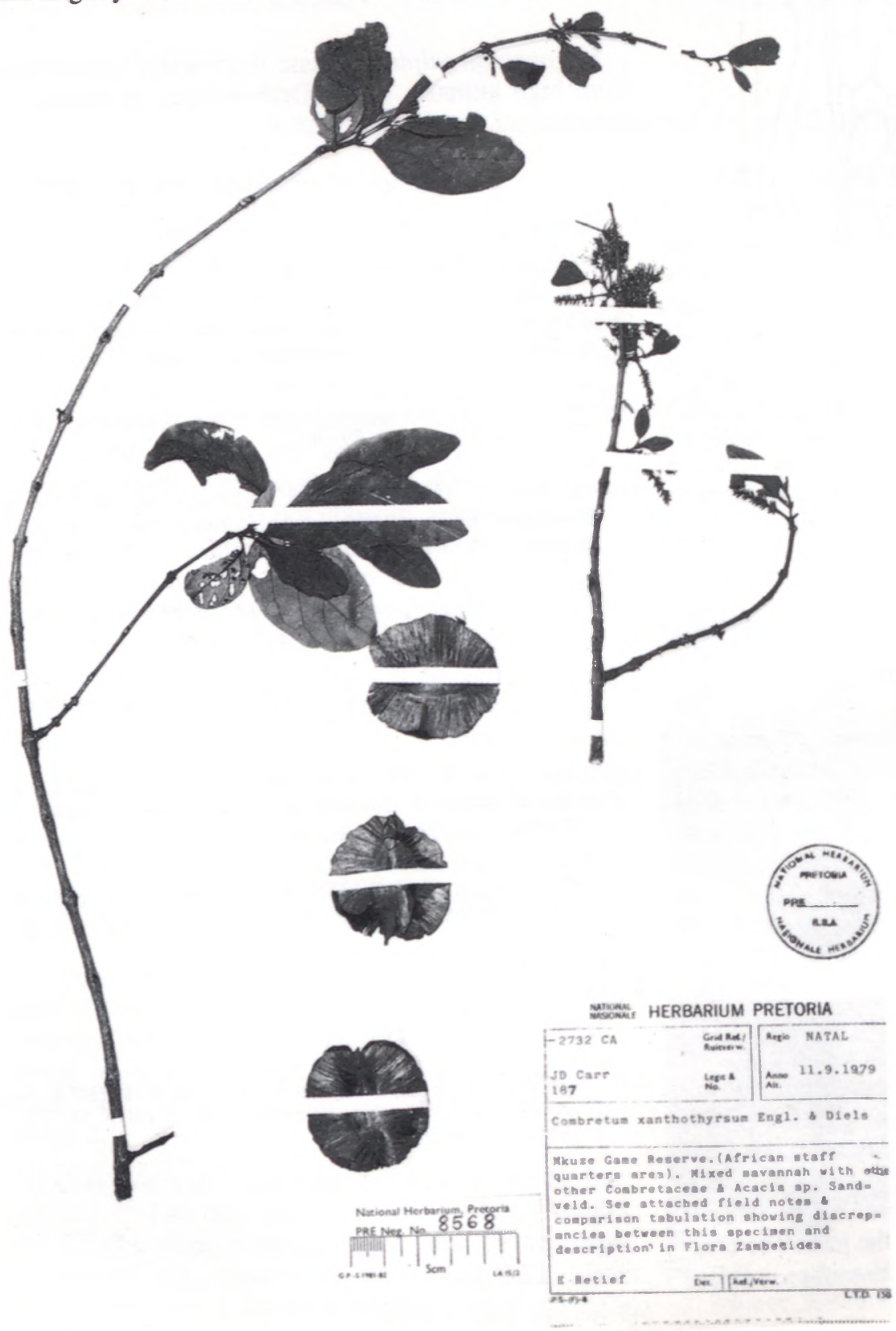


Style light green, $\pm 3,5 \mathrm{~mm}$ long with stigma slightly expanded and darkened. Disc square in outline with long silvery hairs. Fruit 4-winged, up to $50 \times 50 \mathrm{~mm}$, outline subcircular with a wide shallow basal notch and a small apical notch, apical peg up to $1 \mathrm{~mm}$ long, lepidote, stipe up to $20 \mathrm{~mm}$ long, densely lepidote; wings brown-tinged limegreen when ripening, cinnamon when ripe. Seed ellipsoidal, up to $16 \times 9 \mathrm{~mm}$, dark purplish brown. Cotyledons 2 , up to $33 \times 45 \mathrm{~mm}$, transversely elliptic, arising above soil level; petioles $\pm 3 \mathrm{~mm}$ long. Figure 14.

NATAL.-2632 (Bella Vista): $15 \mathrm{~km}$ ENE of Makane's Drift ( $-\mathrm{CD}$ ), Stephen 717 (PRE). 2732 (Ubombo): 3 miles W of Sihangwane store (-AA), Moll 5370 (PRE); I mile E of Pongola pont (-AB), Strey \& Moll 3778 (PRE); Mkuze Game Reserve (-CA). White 10388 (FHO, PRE); eastern side of farm 'Shotton 13810' (-CD), Ward 8793 (PRE).

Combretum mkuzense, which is evidently rare, occurs in the northernmost part of Natal. It is found in mixed woodland in association with other combretaceous species, Acacia, Sclerocarya, Strychnos, Dialium, Newtonia and Albizia. It grows in deep sand at altitudes of up to $100 \mathrm{~m}$ and within $60 \mathrm{~km}$ of the coast.

C. mkuzense normally flowers in September but a second flowering late in March has also been recorded. The flowers are sweetly scented and appear to be beepollinated.

C. mkuzense is placed in the subgenus Combretum, section Macrostigmatea. According to Exell (1978) this section comprises three species, namely $C$. schumannii, $C$. kirkii and $C$. gillettianum. The section can be divided into two subsections on the basis of the disc, which is glabrous with only a very short free margin in $C$. schumannii and with a pilose margin free for $\pm 1 \mathrm{~mm}$ in $C$. kirkii and $C$. gillettianum. $C$. mkuzense has a disc with a pilose margin and is therefore thought to be more closely related to $C$. kirkii and $C$. gillettianum and to C. schumannii (Table 1).

C. mkuzense is most closely allied to $C$. kirkii. There are, however, several differences between the two species. The seeds of $C$. kirkii are as large as $25 \times 9 \mathrm{~mm}$ while the seeds of $C$. mkuzense seen did not exceed 16 $\times 9 \mathrm{~mm}$. Unlike the new species which has a peduncle and rachis sparsely puberulous and densely lepidote, the inflorescence of $C$. kirkii is glabrous except for the scales. Habit differences clearly separate these two species. C. kirkii is a liane with slender, sinuous, flexible, readily damaged apices many of which die back in winter. C. mkuzense is a scrambling shrub with numerous characteristic elongated lateral branches taking off in opposite pairs and at right angles. These branches are fairly straight and maintain appreciable rigidity right up to the apices but sometimes the apices may twine. It has been established, using thin film chromatography, that for each species of Combretum there is a characteristic profile of compounds in the leaf material (Carr \& Rogers 1987). An examination of the profiles of $C$. mkuzense and $C$. kirkii shows similarities but also a significant difference.

Fruits of $C$. zeyheri, a tree which occurs in the same area as the new species, are similar to those of $C . m k u$ zense but the habits of the two species differ so widely that they should not be easily confused. $C$. zeyheri is a small to medium-sized tree while $C$. mkuzense is a scrambling shrub. The scales of the new species (Figure 15) agree well with those of other representatives of the section Macrostigmatea. They differ markedly from those of $C$. xanthothyrsum (sect. Chionanthoideae) (Figure 16) a species which has sometimes been confused with our species.

TABLE 1. - A comparison of Combretum mkuzense, C. kirkii and C. gillettianum. Based partly on Exell (1978)

\begin{tabular}{|c|c|c|c|}
\hline \multirow{2}{*}{ Characters } & \multicolumn{3}{|c|}{ Species } \\
\hline & C. mkuzense & C. $k i r k i i$ & C. gillettianum \\
\hline Habit & $\begin{array}{l}\text { large shrub up to } 5 \mathrm{~m} \text { high, widely } \\
\text { spreading with many near-horizon- } \\
\text { tal lateral branches }\end{array}$ & liane, reaching $15 \mathrm{~m}$ & $\begin{array}{l}\text { shrub to small tree up to } 4 \mathrm{~m} \text { high, } \\
\text { sometimes scandent }\end{array}$ \\
\hline Lateral nerves & $5-7$ pairs & $5-7$ pairs & $3-5$ pairs \\
\hline Bracteoles & $0,5 \mathrm{~mm}$ long & $0,7 \mathrm{~mm}$ long & $1,5 \mathrm{~mm}$ long \\
\hline Lower receptacle & $\begin{array}{l}2-2,3 \mathrm{~mm} \text { long, densely lepidote, } \\
\text { sparsely puberulous }\end{array}$ & $\begin{array}{l}2-3 \mathrm{~mm} \text { long, lepidote otherwise } \\
\text { glabrous }\end{array}$ & $2-2,5 \mathrm{~mm}$ long, tomentellous \\
\hline Upper receptaclc & $\begin{array}{l}3 \times 3 \mathrm{~mm} \text {, cupuliform in upper } \\
\text { part then inf undibuliform. } \\
\text { puberulous and lepidote }\end{array}$ & $\begin{array}{l}3-4 \times 2-3 \mathrm{~mm} \text {, infundibuliform, } \\
\text { lepidote otherwise glabrous }\end{array}$ & $\begin{array}{l}3,5-4 \times 3-4 \mathrm{~mm} \text {, cupuliform, ap- } \\
\text { pressed pubescent with } 4 \text { tomentel- } \\
\text { lous nerves running up into the sepals }\end{array}$ \\
\hline Fruit & up to $50 \times 50 \mathrm{~mm}$, subcircular & $\begin{array}{l}\text { up to } 50 \times 50 \mathrm{~mm} \text {, subcircular } \\
\text { to elliptic }\end{array}$ & $\begin{array}{l}\text { up to } 30 \times 25 \mathrm{~mm} \text {, oval to subcircu- } \\
\text { lar, wings decurrent at the base }\end{array}$ \\
\hline Stipe & up to $20 \mathrm{~mm}$ long & up to $30 \mathrm{~mm}$ long & up to $12 \mathrm{~mm}$ long \\
\hline Distribution & northern Natal & $\begin{array}{l}\text { Zambia, Zimbabwe. Malawi and } \\
\text { Mozambique (confined to the } \\
\text { valley of the Zambezi and its } \\
\text { tributaries) }\end{array}$ & Zambia, Zaire and Tanzania \\
\hline
\end{tabular}




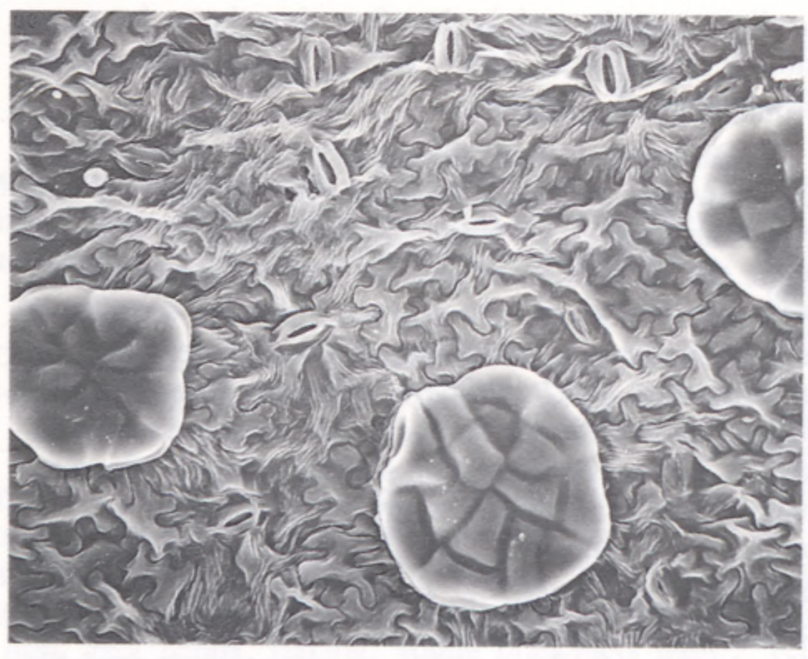

FIGURE 15.-Scales on the leaf surface of Combretum mkuzense Carr $\&$ Retief, $\times 360$. Carr 187 . Scanning electron micrograph taken at the Royal Botanic Gardens, Kew.

\section{REFERENCES}

CARR, J. D. \& ROGERS, B. C. 1987. Chemosystematic studies of the genus Combretum (Combretaceae), part 1. South African Journal of Botany 53: 173-176.

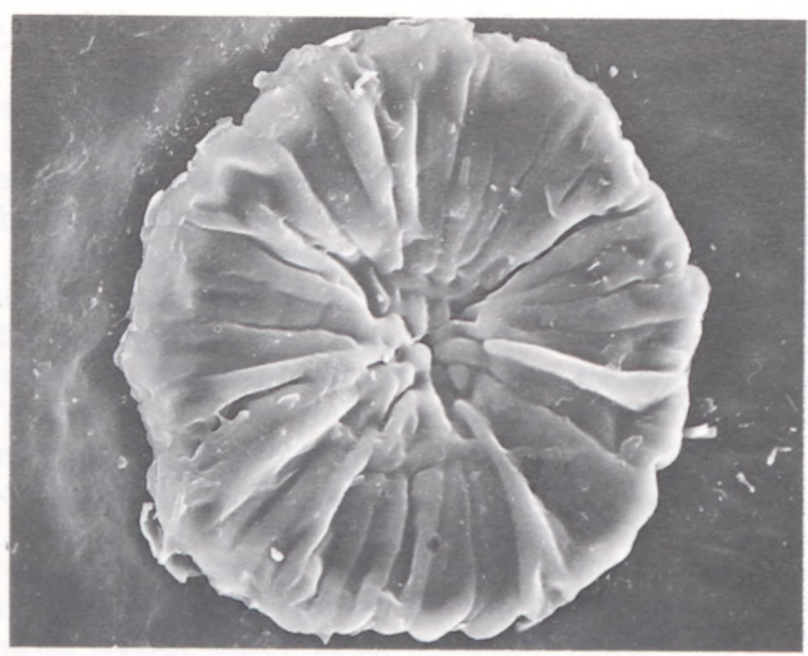

FIGURE 16.-A scale on the leaf surface of Combretum xanthothyrsum Engl. \& Diels, $\times$ 600. Proctor 2759. Scanning electron micrograph taken at the Royal Botanic Gardens, Kew.

EXELL. A. W. 1978. Combretaceae in Flora Zambesiaca 4: $100-183$.

J. D. CARR and E. RETIEF

MS. received: 1987.12.28. 